\title{
Algal Boom Characteristics of Yeongsan River Based on Weir and Estuary Dam Operating Conditions Using EFDC-NIER Model
}

\author{
Darae Kim $^{1}$ (D) and Changmin Shin ${ }^{2, *(D)}$ \\ 1 Department of Living and Built Environment Research, Seoul Institute of Technology (SIT), \\ 8F Maebongsan-ro 37, Mapo-gu, Seoul 03909, Korea; kimdr0910@sit.re.kr \\ 2 Water Quality Assessment Research Division, National Institute of Environment Research (Environmental \\ Research Complex), Hwangyeong 42, Seo-gu, Incheon 22689, Korea \\ * Correspondence: cmshin77@korea.kr
}

check for updates

Citation: Kim, D.; Shin, C. Algal Boom Characteristics of Yeongsan River Based on Weir and Estuary Dam Operating Conditions Using EFDC-NIER Model. Water 2021, 13, 2295. https://doi.org/10.3390/ w13162295

Academic Editor: João Filipe Santos

Received: 15 June 2021

Accepted: 17 August 2021

Published: 21 August 2021

Publisher's Note: MDPI stays neutral with regard to jurisdictional claims in published maps and institutional affiliations.

Copyright: (c) 2021 by the authors. Licensee MDPI, Basel, Switzerland. This article is an open access article distributed under the terms and conditions of the Creative Commons Attribution (CC BY) license (https:// creativecommons.org/licenses/by/ $4.0 /)$.

\begin{abstract}
A number of hydraulic structures have been installed along the Yeongsan River, including an estuary dam and two weirs (Seungchon and Juksan). While these structures aid in regional water security and use and reduce flooding, they reduce water flow in the summer, thereby frequently causing algal blooms. This study simulated algal bloom and water quality characteristics of sections of the Yeongsan River in South Korea under different weir and estuary dam operating conditions using the Environmental Fluid Dynamics Code-National Institute of Environment Research (EFDCNIER) model. Results showed that when the management levels of the Juksan Weir and estuary dam were maintained, simulated water levels were EL. $3.7 \mathrm{~m}$ in the weir section and EL. $-1.2 \mathrm{~m}$ (below average water level of the Yellow Sea) in the dam section. When both the weir and dam were open, the water levels varied with the tide; in contrast, when the Juksan Weir alone was open, the water level was between EL. -1.2 and $-0.9 \mathrm{~m}$, in line with the management level of the estuary dam. Opening the weir alone reduced algal blooms by $72-84 \%$ in the weir region, and opening the estuary dam alone reduced the algal blooms by $83 \%$ in the dam region. This improvement was attributed to the reduced water retention time and dilution due to seawater inflows.
\end{abstract}

Keywords: algae; water quality; Environmental Fluid Dynamics Code-National Institute of Environment Research model; water management

\section{Introduction}

Estuaries are transition areas between land and sea, and environmental changes in an estuary can have a significant influence on the adjacent ocean environment. The construction of estuary dams can be highly beneficial in terms of water security and reducing flood damage; however, these dams may also reduce water flow, thereby frequently causing algal blooms in the summer and eutrophication, which adversely affects the use of agricultural water and the aquatic ecosystem due to the effects of deterioration of water quality, low oxygen levels in the bottom layer, and algal toxins. Furthermore, it has been reported that rapid discharge of eutrophic freshwater from an estuary dam may degrade water quality and biotic integrity of an estuarine system by rapid drops in salinity and variations in phytoplankton biomass and species composition [1].

In the United States, algal abundance per unit of phosphorus has increased in proportion to water residence time in the following sequence: rivers < impoundments < natural lakes, which suggests that water residence time is a useful system-level index that has similar ecological implications for rivers, lakes, and reservoirs [2]. In Lake Frances (Oklahoma-Arkansas, USA), Soballe et al. analyzed an advective limitation to phytoplankton standing crop and suggested a simple equation to empirically predict direct advective effect on phytoplankton biomass in rapidly flushed lakes and impoundment [3]. Meanwhile, in the Des Moines River (Iowa, USA), algae decreased by 65-75\% as they passed 
through two reservoirs, due to algal sedimentation and light limitation and, in both reservoirs, algal loss increased as the residence time and water temperature increased, which is opposite to the algal physiological characteristics in rivers [4]. In both lakes and nearshore coastal waters of Florida, phosphorus is the primary limiting factor for phytoplankton, but the chlorophyll to phosphorus ratios and chlorophyll to biovolume ratios were significantly lower in marine system than lakes [5]. The Yeongsan River is located in the southwest of the Korean Peninsula and flows into the Yellow Sea. Two large weirs (Seungchon and Juksan) and an estuary dam have been installed in the middle and downstream sections of the river, which reduce hydraulic flushing and cause frequent algal blooms during summer.

While it is apparent that reducing water flow due to the construction of weirs and estuary dams can cause eutrophication and low-oxygen layers, studies regarding the impact of their construction on water quality and aquatic ecosystems are limited. Various pollution control scenarios were proposed to improve the water quality of the Porsuk Dam Reservoir in the Porsuk River in Turkey using the QUAL2E for the river and BATHTUB for the reservoir [6]. The water quality prior to and following the construction of the Dadu Weir in the Wu River in Taiwan was reproduced and analyzed using the three-dimensional (3D) Water Quality Analysis Simulation Program (WASP5) model [7].

Since 2017, the Korean Ministry of Environment (ME) has monitored the impact of opening weir floodgates on water quality, aquatic ecosystems, and water use to aid in future planning. Studies have also used 3D water quality models to investigate water quality in Korea. For example, Suh et al. [8] investigated the long-term water quality variability of Shihwa Lake following floodgate operation using the 3D CE-QUAL-ICM model, and the operation of the Seungchon Weir (Yeongsan River) was analyzed using the 3D Estuary, Lake and Coastal Ocean Model and Computational Aquatic Ecosystem Dynamics Model [9]. Furthermore, the impact of changes in hydraulic characteristics, such as a reduction in management level and an increase in flow velocity, on water quality and algal biomass were assessed for the Chilgok Weir and Gangjeong-Goryeong Weir sections of the Nakdong River using the 3D Environmental Fluid Dynamics Code (EFDC) model [10]. The EFDC-NIER model is an improved version of the EFDC model developed by the National Institute of Environment Research (NIER) to simulate multifunctional weir operation, multiple algal species, and vertical algal movement mechanisms [11,12]. The impact of opening the estuary dam on water flow and seawater intrusion in the downstream section of the Yeongsan River has been assessed using the EFDC-NIER model [13]; however, this study did not investigate the combined impacts of the weirs and estuary dam on water quality.

This study aims to (1) construct a model that can simulate water flow and water quality in the mainstream section and estuary dam of the Yeongsan River using the EFDC-NIER model and (2) use the model to assess water flow and water quality characteristics based on the operational conditions of the multifunctional weirs and estuary dam. When the Juksan Weir is fully opened, the water flows of the middle and downstream sections of the weir are directly affected by the estuary dam water level. Therefore, the effects of the operational conditions of both the Juksan Weir and estuary dam are comprehensively assessed in this study.

\section{Materials and Methods}

\subsection{Study Area}

The Yeongsan River originates in the mountains of Yongchubong (EL. $560 \mathrm{~m}$ ), Damyanggun, Jeollanam-do and flows into the Yellow Sea through the estuary dam. The Yeongsan River is approximately $150 \mathrm{~km}$ long and has a basin area of approximately $3551 \mathrm{~km}^{2}$. The Seungchon and Juksan Weirs are located in the middle and downstream sections of the river, respectively. In the upstream area of the Seungchon weir, Pungyeongjeongcheon, Gwangjucheon, Hwangryonggang, and Pyeongdongcheon are merged in sequence. In the Juksan Weir section, Jisukcheon, Jangseongcheon, Yeongsancheon, Manbongcheon, Moonpyeongcheo, Gomakwoncheon, Hampyeongcheon, Sampocheon, and Yeongamcheon are 
merged. Figure 1 shows the geographical location of the Yeongsan River Basin, its major tributaries, meteorological stations, and water quality and water level stations located in the main stream of the Yeongsan River. There are Gwangju 1st (capacity 600,000 $\mathrm{m}^{3} /$ day) and 2nd (capacity 120,000 $\mathrm{m}^{3} /$ day) sewage treatment plants that treat most of the total wastewater generated in the Yeongsan River Basin. The Yeongsan River estuary dam is a tide embankment constructed by filling in the sea approximately $6 \mathrm{~km}$ upstream from the coast of Mokpo City; construction began on 20 January 1978 and was completed on December 1981 as a part of a five-stage comprehensive development plan for the Yeongsan River Basin. The construction of the dam ensured the viability of vast farmlands and secured freshwater resources via the formation of the large Yeongsan Lake $\left(253.6 \times 10^{6} \mathrm{~m}^{3}\right)$. The dam is $4.35 \mathrm{~km}$ long and $20 \mathrm{~m}$ high, with eight original drainage sluices $(30 \mathrm{~m}$ long and $13.6 \mathrm{~m}$ high). Five additional drainage sluices ( $48 \mathrm{~m}$ long and $13.6 \mathrm{~m}$ high) were added in 2014 to respond to the flood level increases attributed to climate change. The normal high water level (NHWL) of the estuary dam is EL. $-1.35 \mathrm{~m}$, and it has been managed for the efficient supply of agricultural, industrial, and residential water and lowland flood prevention. However, the estuary dam has changed the natural ecological environment of the Yeongsan River Basin, evidenced by the ongoing eutrophication and periodic formation of low-oxygen layers in downstream reaches [1].

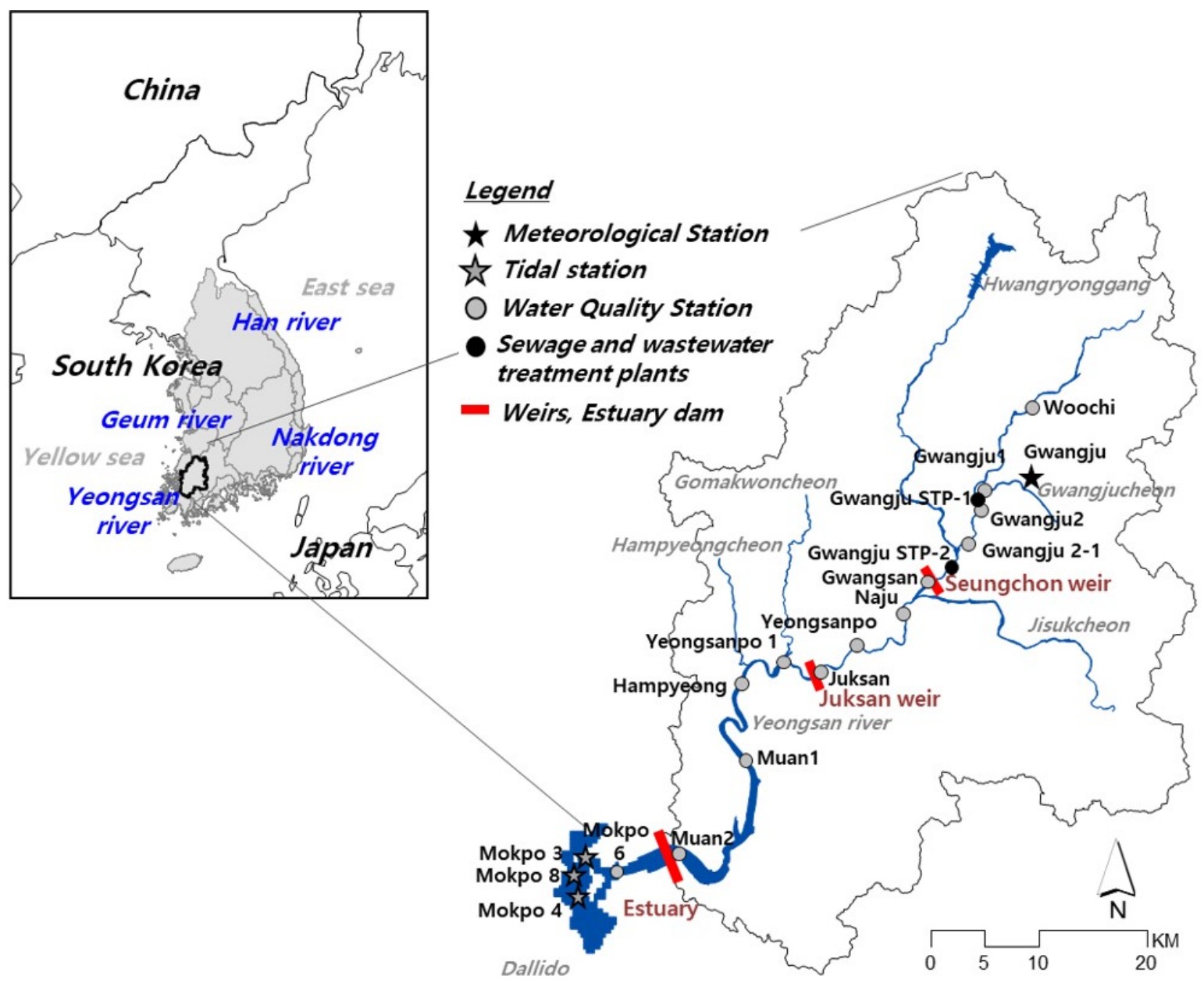

Figure 1. Site map showing the location of the Yeongsan River in Korea and its major tributaries and monitoring stations.

In 2011, 16 weirs were constructed in the main streams of four major rivers in Korea as a part of the Four Major Rivers Restoration Project [14]. The Seungchon and Juksan Weirs were constructed in the middle and downstream sections of the Yeongsan River Basin. The weirs enabled an average water depth of 5-6 $\mathrm{m}$ to be maintained between the weirs based on the management levels of EL. 7.5 and $3.5 \mathrm{~m}$ for the Seungchon and Juksan 
Weirs, respectively. Although weir construction increased water storage in the weir section, it also increased water retention time due to the increased depth and delayed flow [15]. Table 1 summarizes the main specifications of the Seungchon and Juksan Weirs and the estuary dam.

Table 1. Specifications of the Seungchon and Juksan Weirs and the estuary dam.

\begin{tabular}{|c|c|c|c|}
\hline Specification & Seungchon Weir & Juksan Weir & Estuary Dam \\
\hline Management level (EL. m) & 7.5 & 3.5 & -1.35 \\
\hline Volume $\left(10^{6} \mathrm{~m}^{3}\right)$ at management level & 9.0 & 25.7 & 253.6 \\
\hline Surface area $\left(10^{6} \mathrm{~m}^{2}\right)$ at management level & 2.36 & 5.79 & 32.14 \\
\hline Total length (m) & 512 & 184 & 4350 \\
\hline Gate $(\mathrm{m})$ (length $\times$ height $\times$ gate) & $\begin{array}{l}50 \times 5.05 \times 2 \text { gates } \\
30 \times 5.05 \times 2 \text { gates }\end{array}$ & $36.5 \times 7.13 \times 4$ gates & $\begin{array}{l}30 \times 13.6 \times 8 \text { gates } \\
48 \times 13.6 \times 5 \text { gates }\end{array}$ \\
\hline
\end{tabular}

\subsection{EFDC-NIER Model Construction}

The EFDC model was developed by the Virginia Institute of Marine Science in the United States (US) in the early 1990s, and has been maintained by Tetra Tech, Inc. with the support of the US Environmental Protection Agency. The EFDC model is a 3D hydraulic, water quality, and sediment movement numerical model applicable to lakes, rivers, coasts, and estuaries. As the model comprises modules (Hydrodynamics, Water Quality, Sediment Transport, and Toxic modules) it can simulate fluid transport and diffusion, suspended solid behavior, salinity and water temperature changes, water quality and eutrophication mechanisms, and toxic pollutant behavior [16].

The EFDC-NIER model is an improved version of the original EFDC model to simulate multifunctional weirs, multiple algal species, and vertical algal movement mechanisms. The EFDC-NIER model has been used to simulate and forecast the flow and water quality in major rivers and lakes in South Korea [11,12]. The multifunctional weir module used in this study was developed to simulate the operational conditions (discharge, level, etc.) of major hydraulic structures, such as fixed weirs, movable weirs, fishways, and small hydroelectric power plants, as shown in Figure 2. Fixed and movable weir modules can be classified into weirs and orifices depending on the upstream and downstream water level difference. For a fishway module, water discharge to the downstream through the fishway occurs when the water level is higher than the fishway overflow level. With respect to the estuary dam module, it is simulated that discharge to the sea side occurs when the inner water level of estuary dam is generally higher than the management level and the sea tide level according to the operational conditions of the estuary dam.

Weir opening height and water level monitoring data from the Korea Water Resources Corporation (kwater.or.kr) (accessed on 6 January 2020) were used as weir operating data for the multifunctional weir simulation. Dam operating status and water level data from the Yeongsan River Flood Control Office (yeongsanriver.go.kr) (accessed on 6 January 2020) were used as data for the estuary dam simulation. The estuary dam drainage sluices opened only when the water level of the freshwater lake was $0.2 \mathrm{~m}$ higher than the outer tide level in accordance with the Yeongsan River estuary dam drainage sluice operation guidelines [13,17].

The spatial range of the EFDC-NIER model was from the Woochi water quality station in the upstream area of the Yeongsan River to Dalido at the river estuary (Figure 1). A horizontal grid network was constructed considering river maps, embankment boundaries, river cross-section data, captured images, and multifunctional weirs. The total number of horizontal grids was 1731 (1225 for the main stream and 507 outside the estuary dam), and five water depth layers were constructed. Figure 3 shows the horizontal and vertical grid configuration of the EFDC-NIER model [12]. Grid size ranged from $62-510 \mathrm{~m}$ (mean of $214 \mathrm{~m}$ ) wide (dx) and 81-560 m (mean of $271 \mathrm{~m}$ ) in the flow direction (dy). The river bed 
height ranged from EL. $28.6 \mathrm{~m}$ for the uppermost stream to EL. $-21.3 \mathrm{~m}$ for the estuary dam, and from EL. -30.1 to $-0.2 \mathrm{~m}$ (mean of EL. $-14.1 \mathrm{~m}$ ) in the sea outside the estuary dam. The tide level data of Mokpo tidal station and the average water temperature and salinity data of Mokpo 3, 4, and 8 station were used for the sea-side boundary conditions for EFDC-NIER model. Gwangju meteorological station data were used for meteorological conditions, and the national water quality monitoring network data (water.nier.go.kr/Ministry of Environment) (accessed on 6 January 2020) were used for the water quality and flow rates of the inflowing tributaries. Tele-monitoring system data were used for the water quality and flow rate of the treated water from sewage and wastewater treatment plants.

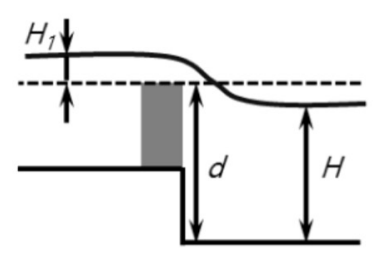

When $\mathrm{H}<\mathrm{d}$,

$$
\mathrm{Q}=\mathrm{C}_{1} \mathrm{~B} \mathrm{H}_{1} \sqrt{2 \mathrm{gH}_{1}}
$$

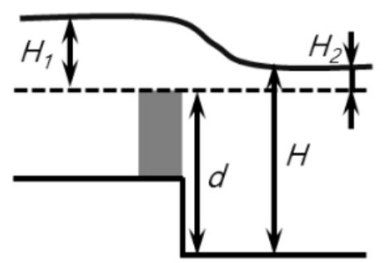

$\mathrm{H} \geq \mathrm{d}$

$$
\mathrm{Q}=2.6 \mathrm{C}_{1} \quad \mathrm{~B} \mathrm{H}_{2} \sqrt{2 \mathrm{~g}\left(\mathrm{H}_{1}-\mathrm{H}_{2}\right)}
$$

(a) Fixed weir

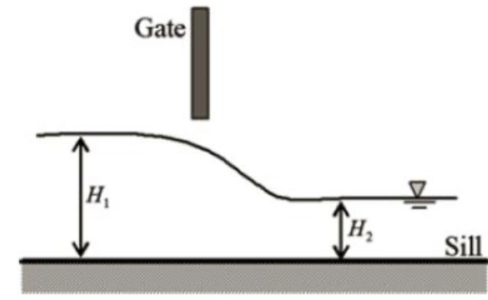

When $\Delta \mathrm{H} \geq \mathrm{H}_{1} / 3$,

$$
\mathrm{Q}_{1}=\mathrm{C}_{2} \mathrm{C}_{3} \mathrm{~B} \mathrm{H}_{1}^{1.5}
$$

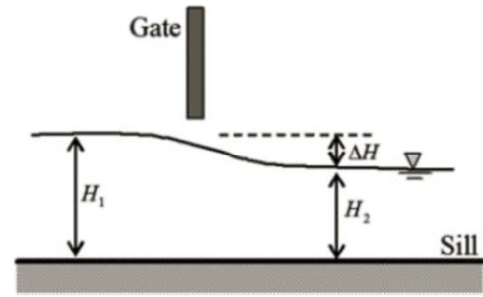

$\Delta \mathrm{H}<\mathrm{H}_{1} / 3$

$\mathrm{Q}_{2}=\mathrm{C}_{4}\left(\mathrm{H}_{1}-\Delta \mathrm{H}\right) \mathrm{B} \sqrt{2 \mathrm{~g} \Delta \mathrm{H}}$

(b) Movable weir (fully open)

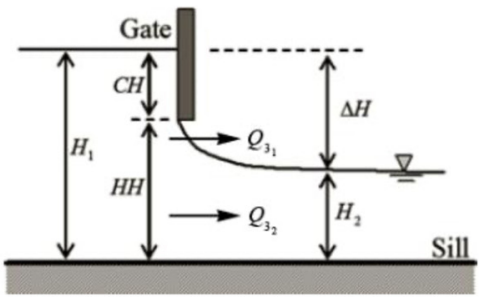

$\mathrm{HH}>\mathrm{H}_{2}$

$$
\begin{gathered}
\mathrm{Q}_{3}=\mathrm{C}_{5}\left(\mathrm{HH}-\mathrm{H}_{2}\right) \mathrm{B} \sqrt{2 \mathrm{~g}(\Delta \mathrm{H}-\mathrm{CH})} \\
+\mathrm{C}_{5 \prime}\left(\mathrm{H}_{1}-\Delta \mathrm{H}\right) \mathrm{B} \sqrt{2 \mathrm{~g} \Delta \mathrm{H}}
\end{gathered}
$$

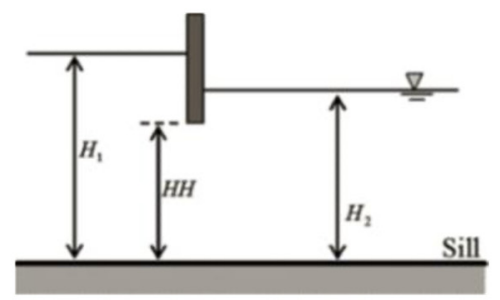

$\mathrm{HH}<\mathrm{H}_{2}$

$$
\mathrm{Q}_{4}=\mathrm{C}_{6} \mathrm{HH} \mathrm{B} \sqrt{2 \mathrm{~g}\left(\mathrm{H}_{1}-\mathrm{H}_{2}\right)}
$$

(c) Movable weir (partially open)

Figure 2. Schematic and flow equations for (a) fixed weir; $(\mathbf{b}, \mathbf{c})$ movable weir operations. $C_{1}-C_{6}$ are the coefficients of discharge and $\mathrm{B}$ is the width of the weir.

\subsection{Algal Simulation Method}

Population at the class level or the total amount of carbon is generally used to quantitatively analyze temporal changes in phytoplankton (i.e., its transition process) from a macroscopic perspective. This is due to the numerous types of phytoplankton to be considered for species or genus classification. The EFDC model can simulate algae by classifying them into three classes (cyanophyceae, bacillariophyceae, and chlorophyceae); however, it cannot easily reproduce the rapid algal blooms of specific species and complex species transitions based on these broad classifications. To address this limitation, a simulation function for multiple algal species was developed by improving the EFDC model [18]. In this study, phytoplankton was simulated using the multiple algal species simulation function, and plankton was grouped according to phytoplankton functional group (PFG) as proposed by Reynolds et al. [19]. PFGs are defined as "a community of algal species with similar characteristics from morphological, physiological, and ecological perspectives," and having similar main habitats [16]. A PFG also exhibits similar tolerance and sensitivity characteristics to changes in the external environment. In this study, groups that represented over $95 \%$ of the total phytoplankton carbon mass were selected by arranging each 
group in the order of the relative carbon-based occupancy and the PFG codons such as M and $\mathrm{H} 1$ that cause harmful algal blooms should be included. Nine groups were classified (Table 2).

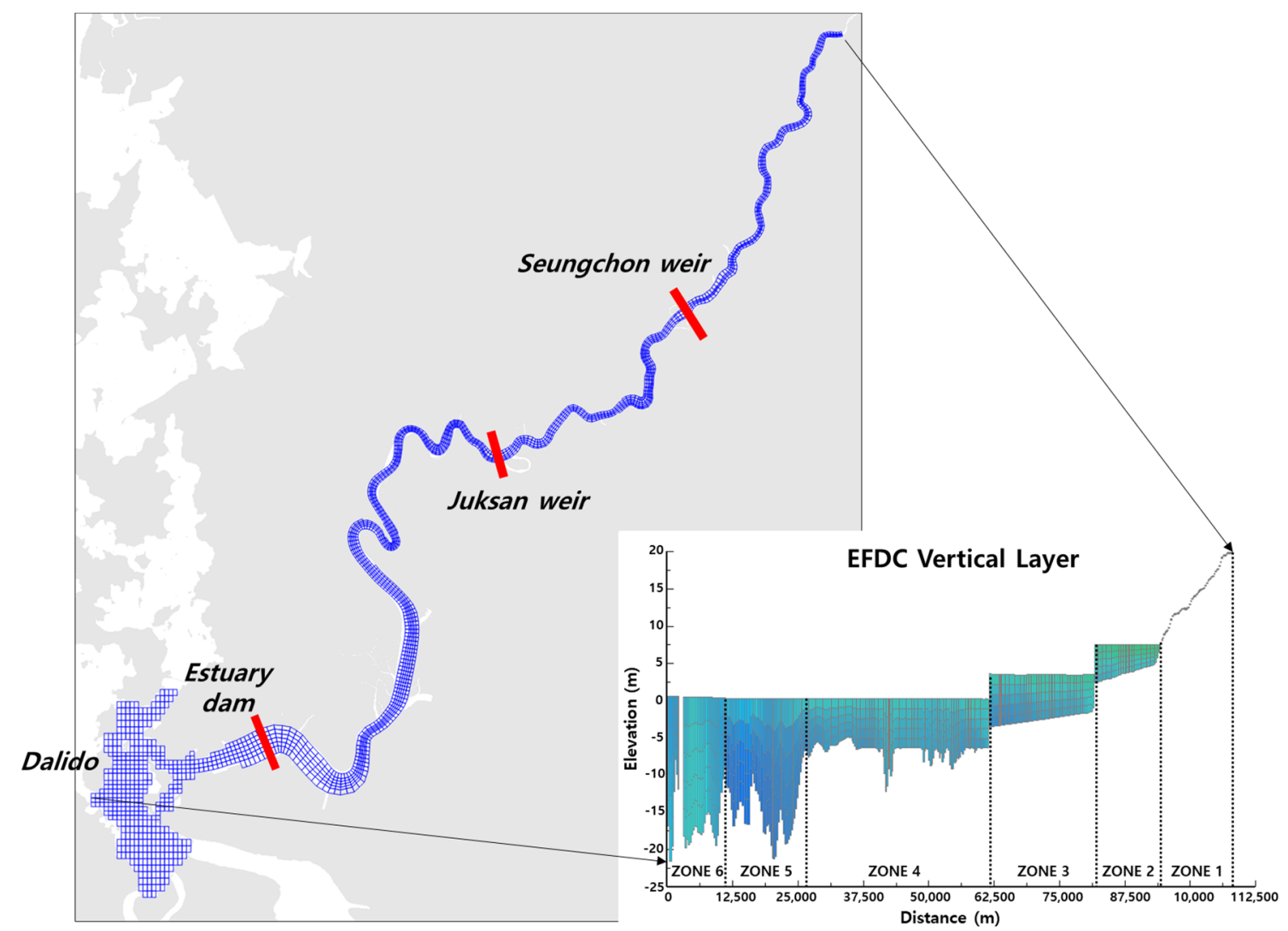

Figure 3. Grid of the Yeongsan River physical domain. Grid spacing ranges from approximately 62-510 $\mathrm{m}$ [12].

Table 2. Trait-separated phytoplankton functional groups in the Yeongsan River [19].

\begin{tabular}{|c|c|c|c|c|c|}
\hline $\begin{array}{l}\text { PFG } \\
\text { Codon }\end{array}$ & Habitat & $\begin{array}{c}\text { Typical } \\
\text { Representatives }\end{array}$ & Tolerances & Sensitivities & $\begin{array}{c}\text { Relative } \\
\text { Abundance of } \\
\text { Carbon Mass (\%) }\end{array}$ \\
\hline M & $\begin{array}{c}\text { Diurnally mixed layers of } \\
\text { small eutrophic, } \\
\text { low-latitude lakes }\end{array}$ & Microcystis & High insolation & $\begin{array}{l}\text { Flushing, low total } \\
\text { light }\end{array}$ & $0.9 \%$ \\
\hline $\mathrm{H} 1$ & $\begin{array}{l}\text { Dinitrogen-fixing } \\
\text { nostocaleans }\end{array}$ & $\begin{array}{l}\text { Anabaena flos-aquae } \\
\text { Aphanizomenon }\end{array}$ & $\begin{array}{l}\text { Low nitrogen, } \\
\text { low carbon }\end{array}$ & $\begin{array}{l}\text { Mixing, poor light, } \\
\text { low phosphorus }\end{array}$ & $0.2 \%$ \\
\hline $\mathrm{P}$ & Eutrophic epilimnia & $\begin{array}{c}\text { Fragilaria crotonensis } \\
\text { Aulacoseira granulata } \\
\text { Staurastrum pingue } \\
\text { Melosira } \\
\text { Closterium }\end{array}$ & $\begin{array}{l}\text { Mild light, C } \\
\text { deficiency }\end{array}$ & $\begin{array}{l}\text { Stratification, Si } \\
\text { depletion }\end{array}$ & $7.5 \%$ \\
\hline $\mathrm{D}$ & $\begin{array}{l}\text { Shallow, enriched turbid } \\
\text { waters, including rivers }\end{array}$ & $\begin{array}{l}\text { Synedra acus } \\
\text { Nitzschia spp } \\
\text { Stephanodiscus } \\
\text { Skeletonema }\end{array}$ & Flushing & Nutrient depletion & $56.1 \%$ \\
\hline G & $\begin{array}{l}\text { Short, nutrient-rich water } \\
\text { columns }\end{array}$ & $\begin{array}{l}\text { Eudorina } \\
\text { Pandorina }\end{array}$ & High light & Nutrient deficiency & $1.2 \%$ \\
\hline $\mathrm{X} 2$ & $\begin{array}{l}\text { Shallow, clear mixed layers } \\
\text { in meso-eutrophic lakes }\end{array}$ & $\begin{array}{l}\text { Chlamydomonas } \\
\text { Cryptomonas }\end{array}$ & Stratification & $\begin{array}{l}\text { Mixing, filter } \\
\text { feeding }\end{array}$ & $3.0 \%$ \\
\hline
\end{tabular}


Table 2. Cont.

\begin{tabular}{|c|c|c|c|c|c|}
\hline $\begin{array}{l}\text { PFG } \\
\text { Codon }\end{array}$ & Habitat & $\begin{array}{c}\text { Typical } \\
\text { Representatives }\end{array}$ & Tolerances & Sensitivities & $\begin{array}{c}\text { Relative } \\
\text { Abundance of } \\
\text { Carbon Mass (\%) }\end{array}$ \\
\hline $\mathrm{J}$ & $\begin{array}{l}\text { Shallow, enriched lakes, } \\
\text { ponds, and rivers }\end{array}$ & $\begin{array}{l}\text { Actinastrum } \\
\text { Coelastrum } \\
\text { Crucigenia } \\
\text { Golenkinia } \\
\text { Pediastrum } \\
\text { Tetrastrum } \\
\text { Scenedesmus }\end{array}$ & & $\begin{array}{l}\text { Settling into low } \\
\text { light }\end{array}$ & $0.5 \%$ \\
\hline $\mathrm{LO}$ & $\begin{array}{l}\text { Summer epilimnia in } \\
\text { mesotrophic lakes }\end{array}$ & $\begin{array}{l}\text { Peridinium } \\
\text { Merismopedia } \\
\text { Chroococcus } \\
\text { Ceratium }\end{array}$ & $\begin{array}{l}\text { Segregated } \\
\text { nutrients }\end{array}$ & $\begin{array}{l}\text { Prolonged or deep } \\
\text { mixing }\end{array}$ & $0.1 \%$ \\
\hline $\mathrm{C}$ & $\begin{array}{c}\text { Mixed, eutrophic } \\
\text { small-medium lakes }\end{array}$ & $\begin{array}{c}\text { Asterionella formosa } \\
\text { Aulacoseira ambigua } \\
\text { Cyclotella }\end{array}$ & $\begin{array}{c}\text { Light, C } \\
\text { deficiencies }\end{array}$ & $\begin{array}{l}\text { Si exhaustion, } \\
\text { stratification }\end{array}$ & $27.4 \%$ \\
\hline
\end{tabular}

To simulate phytoplankton, it is necessary to convert the number of observed algal cells into the mass of carbon (a model parameter). The carbon mass of each group was calculated by multiplying the number of cells for each phytoplankton species by the average carbon mass per cell as follows (Equation (1)): the cellular carbon content can be determined from biovolume based on the regression equation below (Equation (2)) suggested by Menden-Deuer and Lessard [20]. The biovolumes of phytoplankton were referenced in the monitoring project [21] and National Water-Quality Assessment of USGS (http://water.usgw.gov/nawqa) (accessed on 6 January 2020).

Group A carbon mass $(\mathrm{mg} \mathrm{C} / \mathrm{L})=\sum_{\mathrm{i}=1}^{\mathrm{n}}(\text { Algae cell no. }(\text { cells } / \mathrm{L}) \times \operatorname{Algae} \text { carbon mass }(\mathrm{mg} \mathrm{C} / \text { cell }))_{\mathrm{i}}$

where algae are the phytoplankton species included in Group A.

$$
\text { Algae carbon mass }\left(\frac{\mathrm{pgC}}{\text { cell }}\right)=\mathrm{a} \times \text { Biovolume }\left(\mu \mathrm{m}^{3}\right)^{\mathrm{b}}
$$

where the slope (a) and y-intercept (b) of the regression equation are 0.216 and 0.939 , respectively, for phytoplankton excluding diatoms and 0.288 and 0.811 , respectively, for diatoms.

\subsection{Model Assessment}

Shin et al. [13] have previously examined the reproducibility of water flow in the Yeongsan River main stream and the inner and outer sections of the estuary dam using the EFDC-NIER model. The authors found that water level, water temperature, flow velocity, flow rate, and salinity were well simulated at the Seungchon and Juksan Weirs, the estuary dam, and the Mokpo tidal station.

The water quality of the Seungchon Weir, Juksan Weir, and estuary dam was calibrated using data from Gwangsan, Juksan, and Muan 2 points, which are representative points of the National Water Quality Monitoring Network. Monitoring is conducted once a week. If the water depth is $\leq 5 \mathrm{~m}$, only the surface layer is sampled, and if the water depth is $>5 \mathrm{~m}$, the surface layer, middle layer, and lower layer are sampled. The monitoring of phytoplankton was carried out only at the representative point of the weir, and not at the estuary.

Deviation (mean error) and normalized root mean square error (NRMSE) were used as statistical indices for assessing model accuracy. The deviation represents the average 
direction of prediction errors, and NRMSE is used to assess the precision of predicted values (Table 3).

Table 3. Statistical indices used to evaluate model accuracy.

\begin{tabular}{clc}
\hline Statistical Index & Equation & Desired Value \\
\hline Deviation & $\frac{1}{\mathrm{~N}} \sum_{\mathrm{i}=1}^{\mathrm{N}}\left(\mathrm{P}_{\mathrm{i}}-\mathrm{O}_{\mathrm{i}}\right)$ & 0 \\
\hline NRMSE $(\%)$ & $\frac{\sqrt{\frac{1}{\mathrm{~N}} \sum_{\mathrm{i}=1}^{\mathrm{N}}\left(\mathrm{O}_{\mathrm{i}}-\mathrm{P}_{\mathrm{i}}\right)^{2}}}{\overline{\mathrm{O}_{\mathrm{i}}}}$ & 0 \\
\hline
\end{tabular}

$\mathrm{P}_{\mathrm{i}}$ is the simulated value at time $\mathrm{i}, \mathrm{O}_{\mathrm{i}}$ is the observed value at time $\mathrm{i}$, and $\overline{\mathrm{O}_{\mathrm{i}}}$ is the mean of observed values for the entire period.

\subsection{Operational Conditions of the Juksan Weir and Estuary Dam}

When the Juksan Weir is opened, the water flows of the middle and downstream sections of the weir are directly affected by the estuary dam water level. Therefore, the effects of the operational conditions of both the Juksan Weir and estuary dam should be comprehensively assessed.

Changes in water quality were assessed according to the operating conditions of the Juksan Weir and estuary dam. Four scenarios were evaluated, as presented in Table 4. The Juksan Weir was either maintaining the management level (EL. $3.5 \mathrm{~m}$; closed) or the four floodgates were open. The estuary dam was either maintaining NHWL (EL. $-1.35 \mathrm{~m}$; closed) or seawater was being introduced and discharged (open).

Table 4. Scenarios for the operation of the Juksan Weir and estuary dam. Scenario a stands for the closure of both the Juksan Weir and estuary dam, scenario (b) stands for the opening of the Juksan Weir alone, scenario (c) stands for the opening of the estauary dam only, and scenario (d) stands for the opening of both the Juksan Weir and estuary dam.

\begin{tabular}{cccc}
\hline & & \multicolumn{3}{c}{ Juksan Weir } \\
\cline { 3 - 4 } & & Closed (Management Level, EL. 3.5 m) & Open \\
\hline \multirow{2}{*}{$\begin{array}{c}\text { Estuary } \\
\text { dam }\end{array}$} & Closed (NHWL, EL. $-1.35 \mathrm{~m})$ & (a) & (b) \\
\cline { 2 - 4 } & Open (Free tidal) & (c) & (d) \\
\hline
\end{tabular}

\section{Results and Discussion}

\subsection{Algal Bloom and Water Quality Characteristics}

The middle and downstream sections of the Yeongsan River show high phytoplankton concentrations attributed to the increase in retention time caused by the Seungchon and Juksan Weirs and the estuary dam, and the influence of point and non-point pollution sources scattered throughout the basin. Figure $4 \mathrm{a}, \mathrm{c}$ shows the transition characteristics by class, and Figure 4b,d shows the transition characteristics by PFG for 2018. Large quantities of diatoms are produced during early spring due to temperature increases and abundant solar radiation and a transition to green algae and cyanobacteria occurs as summer begins. 
(a) Seongchon Weir (Class)

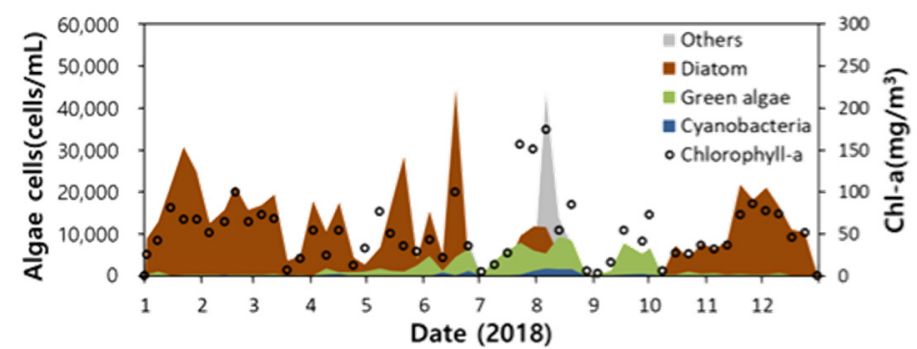

(c) Juksan Weir (Class)

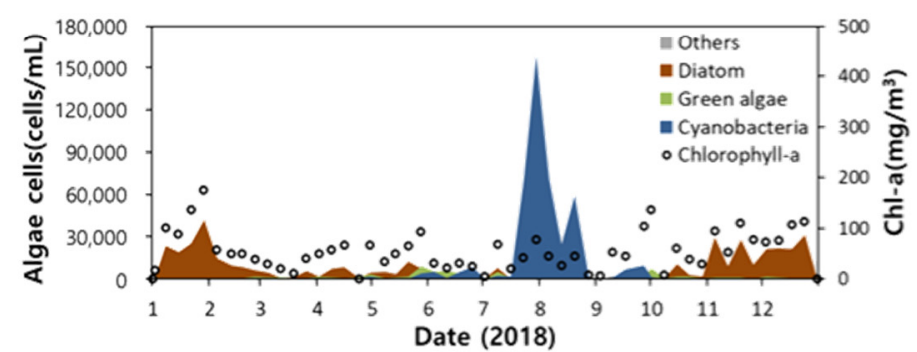

(b) Seongchon Weir (PFG)

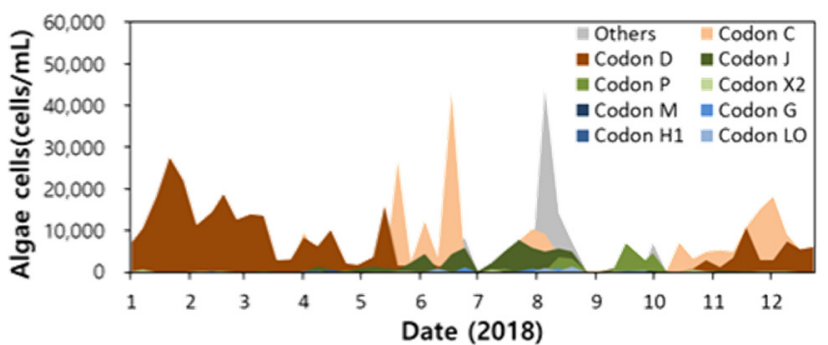

(d) Juksan Weir (PFG)

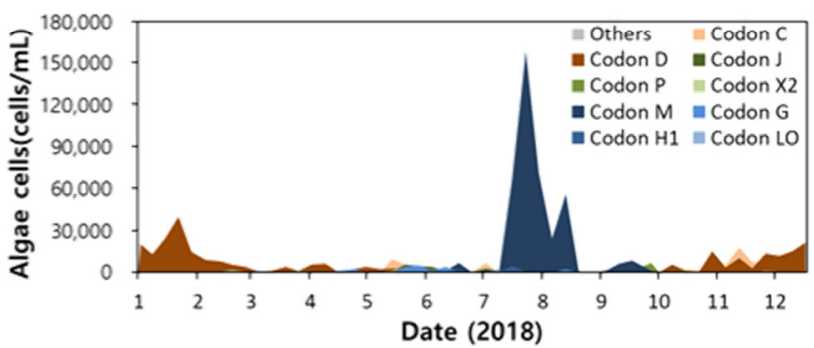

Figure 4. Chlorophyll a concentration and algal cells at the Seungchon Weir by (a) class and (b) phytoplankton functional group (PFG) and at the Juksan Weir by (c) class and (d) PFG for 2018.

The average water qualities from the headwater to the estuary of the Yeongsan River are shown in Table 5.

Table 5. Water qualities from the headwater to the estuary (2014-2018) monitoring stations.

\begin{tabular}{ccccccccc}
\hline & Flow $\left(\mathbf{m}^{3} / \mathbf{s}\right)$ & $\begin{array}{c}\text { Water Temperature } \\
\left({ }^{\circ} \mathbf{C}\right)\end{array}$ & $\begin{array}{c}\text { DO } \\
(\mathbf{m g} / \mathbf{L})\end{array}$ & $\begin{array}{c}\text { BOD } \\
(\mathbf{m g} / \mathbf{L})\end{array}$ & TN (mg/L) & TP (mg/L) & Chlorophyll-a (mg/m $\left.{ }^{3}\right)$ \\
\hline Woochi & 7.5 & 15.6 & 10.1 & 2.7 & 2.11 & 0.095 & 23.4 \\
\hline Gwangju 1 & - & 16.6 & 11.0 & 3.4 & 2.09 & 0.094 & 40.8 \\
\hline Gwangju 2 & - & 17.9 & 10.1 & 5.1 & 7.11 & 0.132 & 33.1 \\
\hline Gwangju 2-1 & - & 18.1 & 10.3 & 5.3 & 7.59 & 0.165 & 52.5 \\
\hline Seungchon weir & 28.3 & 17.1 & 9.3 & 4.9 & 5.56 & 0.150 & 45.0 \\
\hline Naju & - & 17.2 & 11.2 & 4.8 & 4.65 & 0.119 & 63.7 \\
\hline Yeongsanpo & - & 17.5 & 11.5 & 4.3 & 4.62 & 0.106 & 62.8 \\
\hline Juksan weir & 48.8 & 16.5 & 10.1 & 4.1 & 4.27 & 0.114 & 40.9 \\
\hline Yeongsanpo 1 & - & 16.5 & 9.6 & 4.4 & 4.18 & 0.119 & 45.8 \\
\hline Hampyeong & - & 16.5 & 9.6 & 4.2 & 3.95 & 0.111 & 36.6 \\
\hline Muan 1 & - & 16.9 & 10.9 & 3.5 & 3.82 & 0.083 & 43.0 \\
\hline Muan 2 & - & 16.5 & 10.4 & 1.8 & 2.86 & 0.059 & 13.7 \\
\hline
\end{tabular}

\subsection{Model Calibration}

Figure 5 and Table 6 show the results of the EFDC-NIER model in comparison with observations for 2018. Variability in BOD, COD, DO, TN, chlorophyll a, and algae (number of harmful cyanobacterial cells) was well reproduced by the model at the Seungchon and Juksan Weirs and the estuary dam. The average water level deviation ranged from $0.0-0.2 \mathrm{~m}$ and with a deviation of $\leq 1{ }^{\circ} \mathrm{C}$ for water temperature, $\leq 1 \mathrm{mg} / \mathrm{L}$ for BOD concentration, $\leq 1.4 \mathrm{mg} / \mathrm{L}$ for DO concentration, and $\leq 1.0 \mathrm{mg} / \mathrm{L}$ for TN concentration. The chlorophyll a concentration deviation ranged from -27 to $28 \mathrm{mg} / \mathrm{m}^{3}$, and the prediction accuracy 
was lower than other physicochemical water quality metrics. We attribute this to the high spatiotemporal distribution of algae based on weather and environmental conditions. Cyanobacteria were not measured at the Muan 2 point (estuary dam).
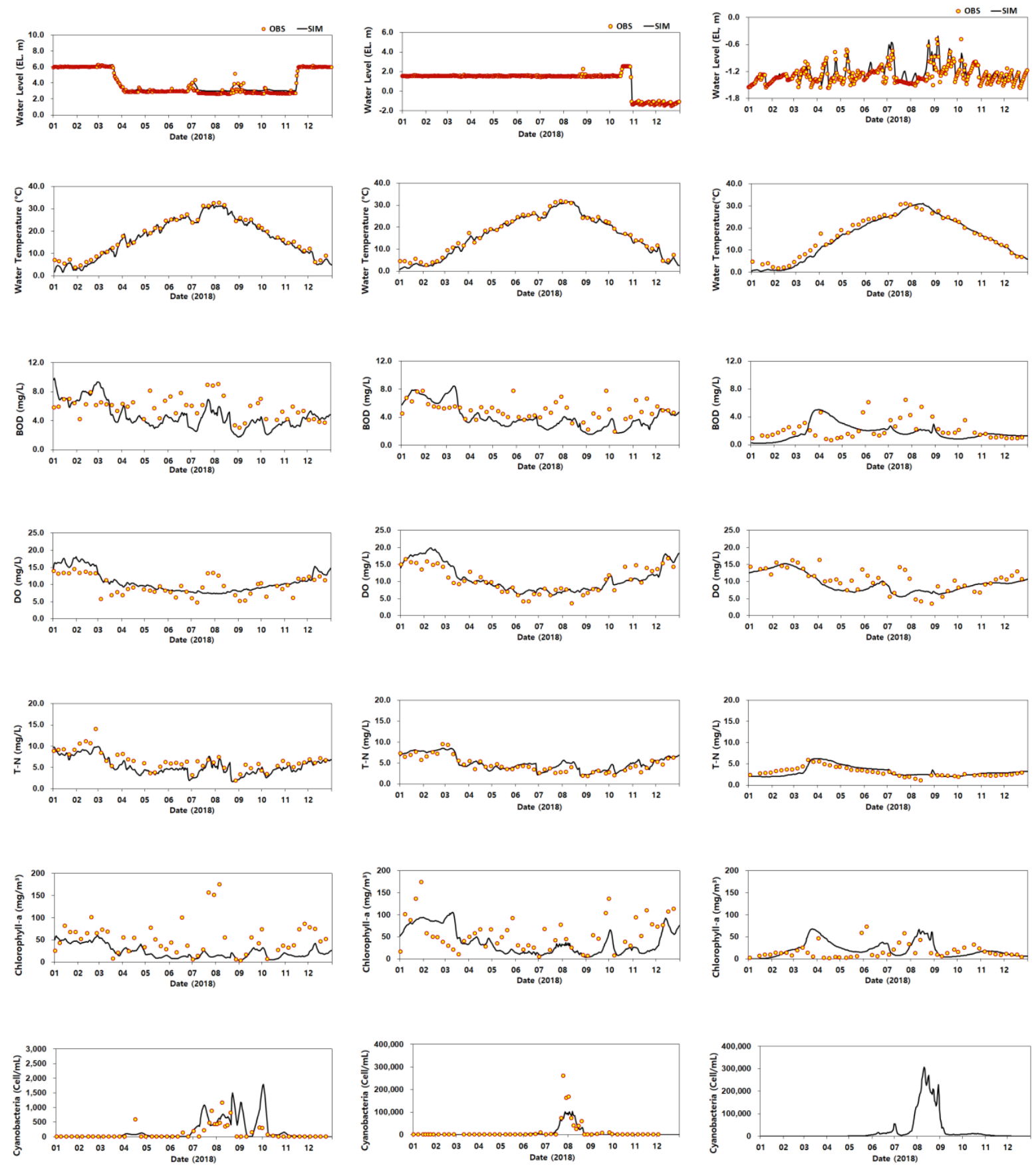

(a) Seungchon Weir

(b) Juksan Weir

(c) Estuary dam

Figure 5. Comparison of observed and simulated values of water quality for the (a) Seungchon Weir, (b) Juksan Weir, and (c) estuary dam for 2018. The number of observed cyanobacterial cells is the sum of cell numbers for the genera Anabena, Aphanizomenon, Microcystis, and Oscillatoria. 
Table 6. Statistical summary of simulated and observed water quality at the Seungchon Weir, Juksan Weir, and estuary dam for 2018

\begin{tabular}{|c|c|c|c|c|c|c|c|}
\hline & $\begin{array}{l}\text { Water Level } \\
(\mathrm{EL}, \mathrm{m})\end{array}$ & $\begin{array}{c}\text { Water } \\
\text { Temperature }\left({ }^{\circ} \mathrm{C}\right)\end{array}$ & BOD (mg/L) & DO (mg/L) & TN (mg/L) & $\begin{array}{l}\text { Chlorophyll a } \\
\left(\mathrm{mg} / \mathrm{m}^{3}\right)\end{array}$ & $\begin{array}{c}\text { Cyanobacteria } \\
\text { (Cells/mL) }\end{array}$ \\
\hline \multicolumn{8}{|c|}{ Seungchon Weir } \\
\hline Observation & 4.0 & 17.3 & 5.8 & 9.6 & 6.509 & 53.2 & 131 \\
\hline Simulation & 4.2 & 16.7 & 4.8 & 10.8 & 5.358 & 25.2 & 196 \\
\hline Deviation & 0.2 & -0.9 & -0.9 & 1.4 & -0.9 & -27.6 & 82.0 \\
\hline NRMSE (\%) & 7.3 & 6.9 & 35.3 & 30.2 & 21.198 & 87.2 & 287.0 \\
\hline \multicolumn{8}{|c|}{ Juksan Weir } \\
\hline Observation & 1.6 & 16.5 & 5.0 & 10.3 & 4.577 & 56.4 & 16,781 \\
\hline Simulation & 1.6 & 16.0 & 4.2 & 11.5 & 5.045 & 47.1 & 10,014 \\
\hline Deviation & 0.0 & -0.7 & -0.8 & 1.3 & 0.5 & -10.8 & -6285 \\
\hline NRMSE (\%) & 5.2 & 6.5 & 36.4 & 23.0 & 21.616 & 68.4 & 220.1 \\
\hline \multicolumn{8}{|c|}{ Estuary dam } \\
\hline Observation & -1.3 & 16.6 & 2.2 & 10.4 & 2.980 & 16.2 & - \\
\hline Simulation & -1.2 & 15.7 & 1.8 & 9.4 & 3.160 & 21.1 & 23,857 \\
\hline Deviation & 0.1 & -0.8 & 0.5 & -0.8 & 0.3 & 27.7 & - \\
\hline NRMSE (\%) & -9.3 & 11.0 & 83.7 & 25.9 & 26.510 & 143.0 & - \\
\hline
\end{tabular}

Table 7 shows the ranges of the principal water quality parameters of the EFDC-NIER model. The parameters related to algal growth were applied differently depending on the spatial zone of the model. The parameter values were adjusted within the allowable range; simulated values closest to the observed values were applied.

Table 7. Principal water quality calibration parameters and calibrated values in this study. EFDC model parameter.

\begin{tabular}{|c|c|c|c|c|c|c|c|}
\hline & \multirow{2}{*}{ Unit } & \multirow{2}{*}{ Definition } & \multicolumn{5}{|c|}{ Calibrated Value Range for Each Codon } \\
\hline & & & $\mathbf{M}$ & H1 & $\mathbf{P}$ & $\mathbf{D}$ & Others \\
\hline PMx & /day & Max. growth rate for algae & $1.0-2.4$ & $1.0-3.0$ & $0.5-3.0$ & $0.4-1.0$ & $0.5-2.0$ \\
\hline BMRx & /day & Basal metabolism rate for algae & 0.05 & 0.05 & 0.05 & 0.01 & $0.01-0.05$ \\
\hline PRRx & /day & Predation rate on algae & 0.05 & 0.05 & 0.05 & 0.01 & $0.01-0.05$ \\
\hline KHPx & $\mathrm{mg} / \mathrm{L}$ & $\begin{array}{l}\text { Phosphorus half-saturation for } \\
\text { algae }\end{array}$ & 0.018 & 0.018 & 0.006 & 0.006 & $0.006-0.010$ \\
\hline TM lowx & ${ }^{\circ} \mathrm{C}$ & $\begin{array}{l}\text { Lower optimal temp. for } \\
\text { cyanobacterial growth }\end{array}$ & 20 & 18 & 15 & 2 & 2 \\
\hline TM upp & ${ }^{\circ} \mathrm{C}$ & $\begin{array}{l}\text { Upper optimal temp. for } \\
\text { cyanobacterial growth }\end{array}$ & 35 & 30 & 20 & 5 & 35 \\
\hline $\mathrm{CIa}, \mathrm{Clb}, \mathrm{Clc}$ & - & $\begin{array}{l}\text { Weighting factor for solar } \\
\text { radiation at } 0,-1 \text {, and } 2 \text { days }\end{array}$ & \multicolumn{5}{|c|}{$0.80,0.15,0.05$} \\
\hline CPprm1 & $\mathrm{g} \mathrm{C} / \mathrm{g} \mathrm{P}$ & $\begin{array}{l}\text { Minimum algae } \\
\text { carbon-to-phosphorus ratio }\end{array}$ & \multicolumn{5}{|c|}{50} \\
\hline CPprm2 & $\mathrm{gC}_{\mathrm{g}} \mathrm{P}$ & $\begin{array}{l}\text { Difference between min. and max. } \\
\text { algal } C / P \text { ratio }\end{array}$ & \multicolumn{5}{|c|}{50} \\
\hline CPprm3 & $/ \mathrm{mg} / \mathrm{L}$ & $\begin{array}{l}\text { Effect of dissolved phosphate } \\
\text { conc. on algal C/P ratio }\end{array}$ & \multicolumn{5}{|c|}{20} \\
\hline ANCx & $\mathrm{g} \mathrm{N} / \mathrm{g} \mathrm{C}$ & Nitrogen-to-carbon ratio for algae & \multicolumn{5}{|c|}{0.12} \\
\hline
\end{tabular}




\subsection{Algal Bloom Characteristics According to the Operating Conditions of Juksan Weir and the Estuary Dam}

Tables 8 and 9 and Figures $6-8$ show the simulation results of the water level and algal bloom characteristics according to the operating conditions of the Juksan Weir and estuary dam. When the Juksan Weir and estuary dam are both closed, the Juksan Weir and estuary dam sections maintain water levels of 3.7 and $-1.2 \mathrm{~m}$, respectively. When the weir is opened and the dam closed, the region is connected as a single water body and the entire section exhibits similar water levels. Simulations suggest that a water level between -1.2 and $-0.9 \mathrm{~m}$ is maintained due to the influence of the management level of the estuary dam. When both the weir and dam are opened, the water level varies depending on the outer tide and maintains an average of $0.2-0.6 \mathrm{~m}$.

Table 8. Simulation results according to the operating conditions of the Juksan Weir and estuary dam.

\begin{tabular}{|c|c|c|c|c|c|c|}
\hline \multirow[b]{2}{*}{ Variables } & \multirow[b]{2}{*}{ Section } & \multirow{2}{*}{$\begin{array}{l}\text { Location (from Weir } \\
\text { and Dam) }\end{array}$} & \multicolumn{2}{|c|}{ Estuary Dam: Closed } & \multicolumn{2}{|c|}{ Estuary Dam: Open } \\
\hline & & & (a) Weir Closed & $\begin{array}{l}\text { (b) Weir Open } \\
\text { (b)-(a), \%) * }\end{array}$ & $\begin{array}{l}\text { (c) Weir Closed } \\
\text { (ㄷ)-(a), \%)* }\end{array}$ & $\begin{array}{l}\text { (d) Weir Open } \\
\text { (d)-(c), \%) * }\end{array}$ \\
\hline \multirow{4}{*}{ Water level (EL. m) } & \multirow{3}{*}{ Juksan Weir } & Naju (15.5km) & 3.7 & -0.9 & 3.7 & 0.6 \\
\hline & & Yeongsanpo $(6.6 \mathrm{~km})$ & 3.7 & -1.1 & 3.7 & 0.5 \\
\hline & & Juksan $(0.8$ km) & 3.7 & -1.2 & 3.7 & 0.4 \\
\hline & Estuary dam & Muan $2(0.2 \mathrm{~km})$ & -1.2 & -1.2 & 0.2 & 0.2 \\
\hline \multirow{4}{*}{$\begin{array}{l}\text { Cyanobacteria } \\
\text { (Jun-Sep average; } \\
\quad(\text { cells } / \mathrm{mL})\end{array}$} & \multirow{3}{*}{ Juksan Weir } & Naju $(15.5$ km) & 3201 & $889(72 \% \downarrow)$ & $3195(-)$ & $2169(32 \% \downarrow)$ \\
\hline & & Yeongsanpo $(6.6 \mathrm{~km})$ & 8385 & $1578(81 \% \downarrow)$ & $8405(-)$ & $8265(-)$ \\
\hline & & Juksan $(0.8$ km) & 38,185 & $6099(84 \% \downarrow)$ & $38,185(-)$ & $37,601(-)$ \\
\hline & Estuary dam & Muan $2(0.2 \mathrm{~km})$ & 67,041 & $65,978(-)$ & $11,313(83 \% \downarrow)$ & $12,706(-)$ \\
\hline \multirow{4}{*}{$\begin{array}{l}\text { Chlorophyll a } \\
\left(\mathrm{mg} / \mathrm{m}^{3}\right)\end{array}$} & \multirow{3}{*}{ Juksan Weir } & Naju $(15.5$ km) & 31.0 & $28.2(9 \% \downarrow)$ & $31.0(-)$ & $31.7(-)$ \\
\hline & & Yeongsanpo $(6.6 \mathrm{~km})$ & 36.4 & $30.4(16 \% \downarrow)$ & $36.5(-)$ & $38.7(-)$ \\
\hline & & Juksan $(0.8$ km) & 48.3 & $42.8(11 \% \downarrow)$ & $48.3(-)$ & $51.5(-)$ \\
\hline & Estuary dam & Muan $2(0.2 \mathrm{~km})$ & 25.3 & $25.8(-)$ & $7.4(71 \% \downarrow)$ & $7.9(-)$ \\
\hline
\end{tabular}

* A $t$-test was applied to evaluate the differences between weir and dam operational conditions. When the change was significant $(95 \%$ confidence level), a reduction is indicated with " $\downarrow$ ". Changes with no significance are indicated with "-".

Table 9. Simulations of water level and retention time in the Juksan Weir section according to the operating conditions of the Juksan Weir and estuary dam (averaged from June to September 2018).

\begin{tabular}{|c|c|c|c|c|c|}
\hline \multicolumn{2}{|c|}{ Scenario } & \multirow{2}{*}{$\begin{array}{l}\text { Water Level (EL. } \\
\text { m) (Min-Max) }\end{array}$} & \multirow{2}{*}{$\begin{array}{l}\text { Water Volume } \\
\left(\mathrm{m}^{3}\right) \text { (Min-Max) }\end{array}$} & \multirow{2}{*}{$\begin{array}{l}\text { Flow }\left(\mathrm{m}^{3} / \mathrm{s}\right) \\
\text { (Min-Max) }\end{array}$} & \multirow{2}{*}{$\begin{array}{l}\text { Retention Time } \\
\text { (Day) (Min-Max) }\end{array}$} \\
\hline Estuary Dam & Juksan Weir & & & & \\
\hline \multirow{2}{*}{ Closed } & Closed & $3.8(3.6-4.6)$ & $27.8(26.4-34.1)$ & $102.8(9.0-1318.1)$ & $11.2(0.3-34.1)$ \\
\hline & Open & $-1.1(-1.5--0.2)$ & $4.9(3.5-8.4)$ & $102.8(9.0-1318.1)$ & $1.8(0.1-5.5)$ \\
\hline \multirow{2}{*}{ Open } & Closed & $3.8(3.6-4.6)$ & $27.8(26.4-34.1)$ & $102.8(9.0-1318.1)$ & $11.2(0.3-34.1)$ \\
\hline & Open & $0.6(0.2-1.3)$ & $12.3(10.3-12.3)$ & $102.8(9.0-1318.1)$ & $4.9(0.1-14.3)$ \\
\hline
\end{tabular}




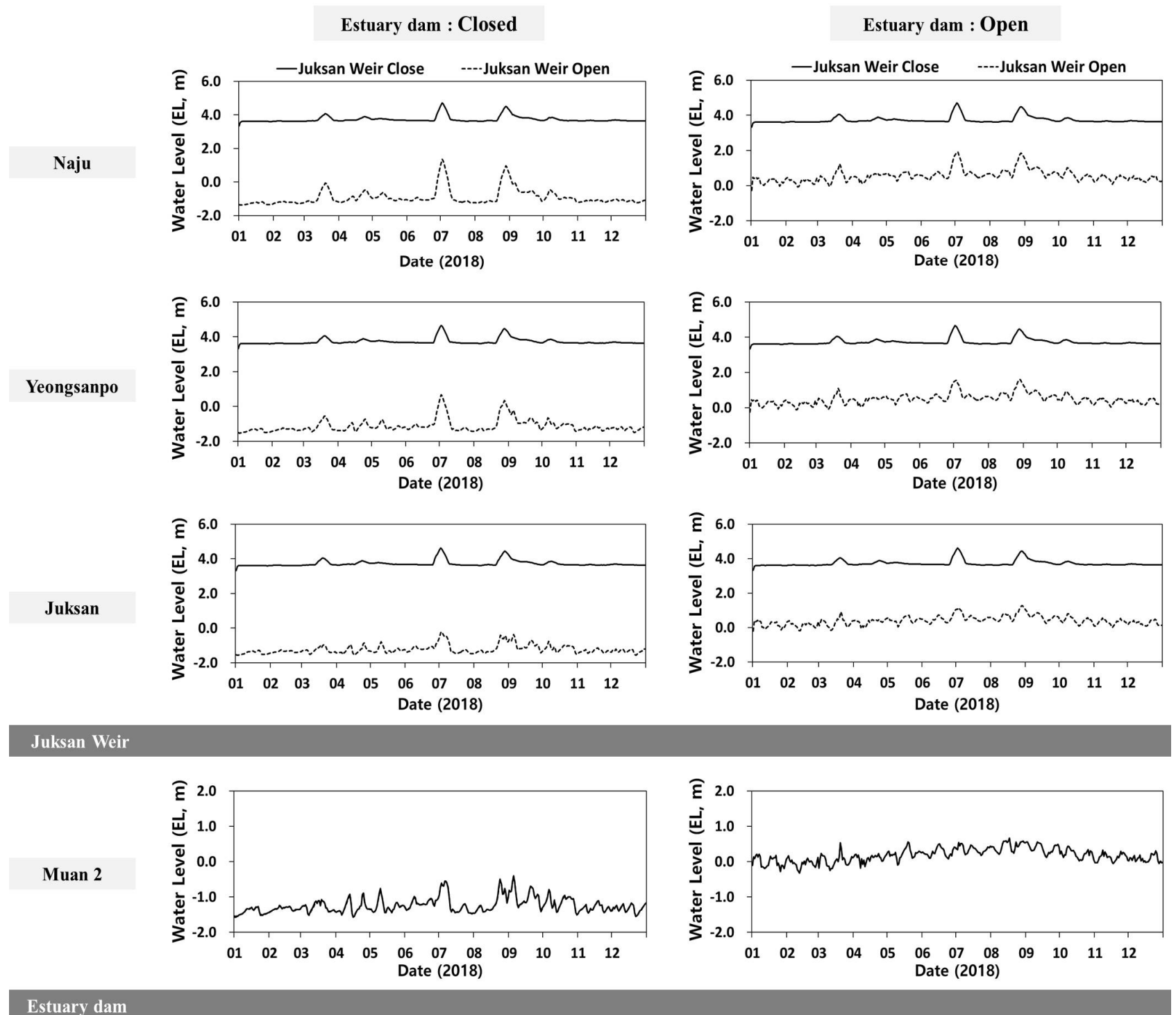

Figure 6. Simulated water levels according to the operating conditions of the Juksan Weir and estuary dam.

Opening the Juksan Weir and estuary dam significantly decreased algal blooms due to reduced retention time and dilution due to seawater inflow. The number of cyanobacterial cells in the Juksan Weir section ranged between 3201 and 38,185 cells/mL when the Juksan Weir and estuary dam were closed; however, this number decreased by $72-84 \%$ to $889-6099$ cells $/ \mathrm{mL}$ when the Juksan Weir alone was opened. This is because the average retention time decreases from 11.2 to 1.8 days due to a reduction in water level, as shown in Table 7. Soballe et al. $(1985,1987)$ reported that algal abundance per unit of phosphorus increased in proportion to water residence time in the following sequence: rivers $<\mathrm{im}$ poundments $<$ natural lakes, and the residence time is a direct limitation to phytoplankton biomass $[2,3]$.

Conversely, when both the Juksan Weir and estuary dam are opened, algal blooms in the Juksan Weir section are decreased by $0-32 \%$, a smaller reduction than that when the Juksan Weir alone is opened. This is because the increased water level further reduces the water flow and increases the retention time under the direct influence of the outer tide level. 


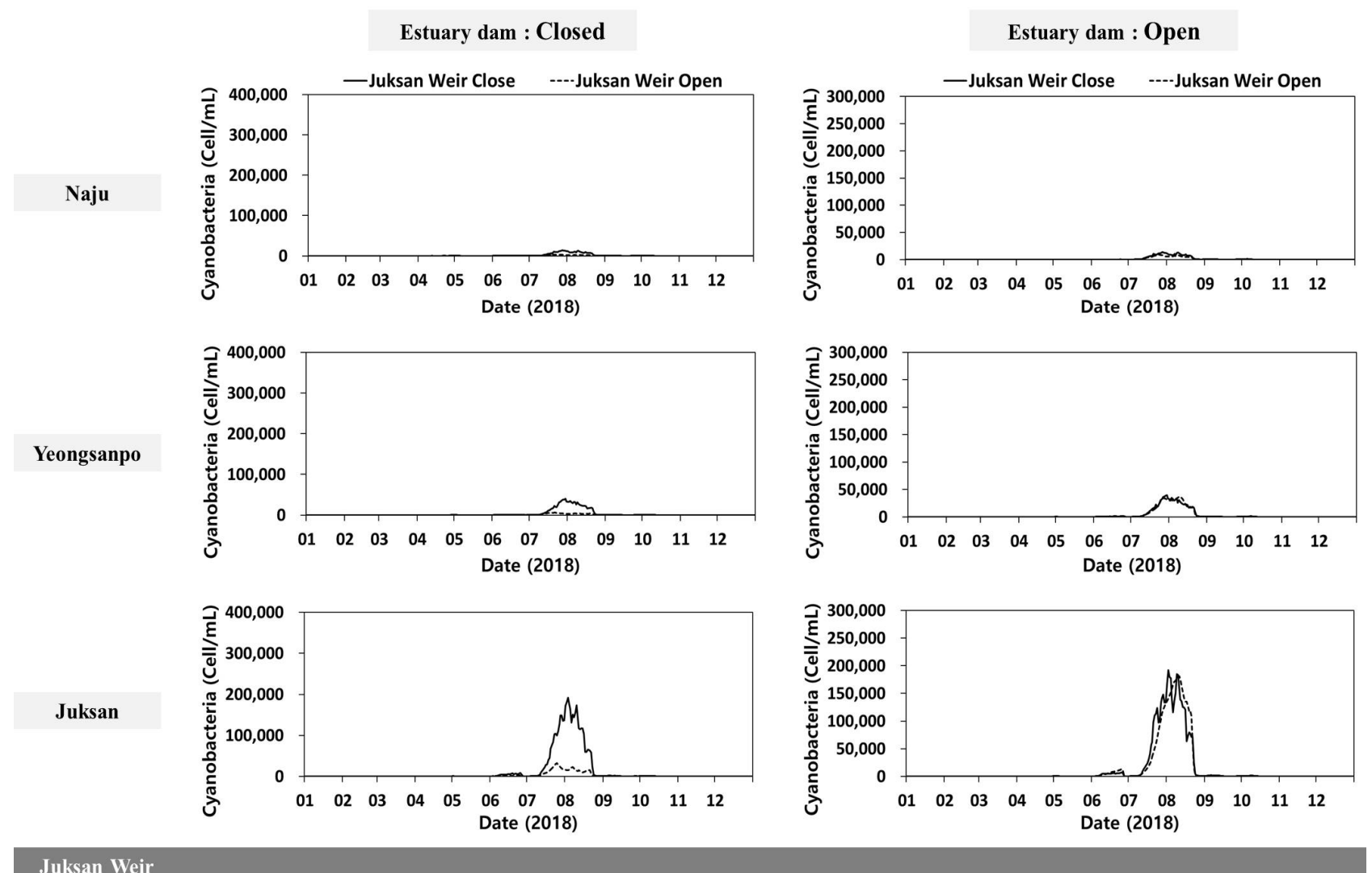

Juksan Weir
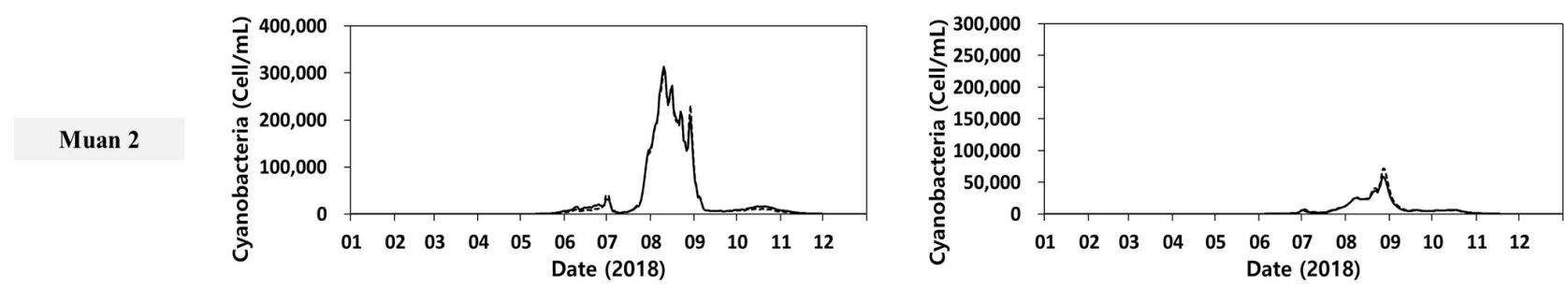

Estuary dam

Figure 7. Simulated cyanobacterial concentrations according to the operating conditions of the Juksan Weir and estuary dam.

The simulated number of algal cells in the estuary dam section was 67,041 cells $/ \mathrm{mL}$ when the estuary dam was closed; however, this decreased to 11,313 cells $/ \mathrm{mL}(83 \%)$ when the estuary dam alone was opened due to dilution by seawater inflows. Conversely, the impact of opening both the estuary dam and the Juksan Weir (scenario 4) was insignificant. Hoyer et al. (2002) reported that the chlorophyll to phosphorus ratios and chlorophyll to biovolume ratios were significantly lower in marine system than in lakes of Florida [5].

Similar to algal blooms, the model showed that opening the Juksan Weir and estuary dam decreased the chlorophyll a concentration due to a reduced retention time caused by water level changes and seawater dilution impacts; however, the decrease was smaller than that of algal blooms. This is because diatoms, which are dominant during the winter, can grow in a relatively stable manner with low water levels or fast water flow (Codon $D$ in Table 2). 




Figure 8. Simulated chlorophyll a concentrations according to the operating conditions of the Juksan Weir and estuary dam.

\section{Conclusions}

In the middle and downstream sections of the Yeongsan River, water flow is reduced by the Seungchon and Juksan Weirs and an estuary dam, causing frequent algal blooms and hypoxic layers due to the increased retention time during the summer. This study investigated the impacts of operating the Juksan Weir and estuary dam, in terms of water quality and algal bloom characteristics, in the middle and downstream sections of the Yeongsan River. A water quality prediction model was constructed and validated for the mainstream and estuary dam sections using the 3D EFDC-NIER model. A multifunctional weir module was applied to reproduce water flow characteristics of the weirs and estuary dam, and a simulation module for multiple algal species was applied to reflect the occurrence, transition, and extinction characteristics of various algal species. The model was then used to compare and assess water flow and algal bloom characteristics according to the operating conditions of the Juksan Weir and estuary dam. The model validation results indicated that the model could reproduce the water flow and levels under different operating conditions well. Furthermore, the spatiotemporal changes in water quality were generally simulated with a high degree of accuracy.

When the Juksan Weir and estuary dam were closed (the management water level was maintained), the Juksan Weir and estuary dam sections maintained the average wa- 
ter levels of EL 3.7 and $-1.2 \mathrm{~m}$, respectively. Average cyanobacterial abundance was $3201-38,185$ cells $/ \mathrm{mL}$ for the Juksan Weir section and 67,041 cells $/ \mathrm{mL}$ for the estuary dam during the summer, suggesting relatively high levels of algae. Scenario simulations showed that opening the Juksan Weir while keeping the estuary dam closed would reduce algal blooms by an average of $72-84 \%$ in the Juksan Weir section. This was attributed to increased water flow and reduced retention time caused by decreased water levels. Furthermore, opening the estuary dam while keeping the Juksan Weir closed would reduce algal blooms by an average of $83 \%$ due to dilution by seawater inflow. However, when both the Juksan Weir and estuary dam were open, simulations showed that the algal bloom reduction in the middle and downstream sections of the Juksan Weir was smaller than the reductions from opening the Juksan Weir alone. This was attributed to the increased water level caused by the outer tide level.

The occurrence of algal blooms was significantly decreased due to the increased water flow and dilution caused by seawater inflow when the Juksan Weir and the estuary were opened. However, there might be restrictions on the use of agricultural water due to the increase in salinity due to seawater inflows and a decrease in the groundwater level around the river due to the decrease in the river water level. According to the guidelines for the evaluation of water quality for irrigation (FAO, 1994), water with a salinity of $<0.7 \mathrm{dS} / \mathrm{m}$ would have no restriction on use, while water in the range of $0.7-3.0 \mathrm{dS} / \mathrm{m}$ would have a slight to moderate restriction, and water with a salinity of $>3.0 \mathrm{dS} / \mathrm{m}$ would have a severe restriction on use [22].

The EFDC-NIER model for the Yeongsan River main stream and estuary can be used to analyze water flow and water quality characteristics according to the operational conditions of the multifunctional weirs and estuary dam in the river system, and to establish and evaluate plans for improving the water quality and aquatic ecosystems of the Yeongsan River. The occurrence of algae in rivers and estuaries is affected by various factors such as changes in point/non-point pollutant sources in the watershed, weather, and the opening condition of weirs and estuary dams. Therefore, the scenario simulation results of this study provide a reference for relative comparison values according to the opening conditions.

Author Contributions: Conceptualization, C.S.; data curation, D.K.; formal analysis, D.K.; investigation, D.K.; methodology, D.K. and C.S.; resources, C.S.; software, D.K.; validation, C.S.; writingoriginal draft, D.K.; writing-review and editing, D.K. and C.S.; project administration, C.S.; funding acquisition, C.S. Both authors have read and agreed to the published version of the manuscript.

Funding: This work was supported by a grant from the National Institute of Environmental Research (NIER), funded by the Ministry of Environment of the Republic of Korea (NIER-RP2019-130).

Institutional Review Board Statement: Not applicable.

Informed Consent Statement: Not applicable.

Data Availability Statement: Not applicable.

Acknowledgments: We are thankful to NIER for funding (NIER-RP2019-130).

Conflicts of Interest: The authors declare no conflict of interest.

\section{References}

1. Shin, Y.S.; Jeong, B.K. Short-term variations of phytoplankton communities in response to anthropogenic stressors in a highly altered temperate estuary. Estuar. Coast. Shelf Sci. 2015, 156, 83-91. [CrossRef]

2. Soballe, D.M.; Kimmel, B.L. A large-scale comparison of factors influencing phytoplankton abundance in rivers, lakes, and impoundments. Ecology 1987, 68, 1943-1954. [CrossRef] [PubMed]

3. Soballe, D.M.; Threldkeld, S.T. Advection, phytoplankton biomass, and nutrient transformations in a rapidly flushed impoundment. Arch. Hydrobiol. 1985, 105, 187-203.

4. Soballe, D.M.; Bachmann, R.W. Influence of reservoir transit on riverine algal transport and abundance. Can. J. Fish. Aquat. Sci. 1984, 41, 1803-1813. [CrossRef]

5. Hoyer, M.V.; Frazer, T.K.; Notestein, S.K.; Canfield, D.E. Nutrient, Chlorophyll, and Water Clarity Relationships in Florida's Nearshore Coastal Waters with Comparisons to Freshwater lakes. Can. J. Fish. Aquat. Sci. 2002, 59, 1024-1031. [CrossRef] 
6. Muhammetoglu, A.; Muhammetoglu, H.; Oktas, S.; Ozgokcen, L.; Soyupak, S. Impact assessment of different management scenarios on water quality of Porsuk River and dam system. Water Resour. Manag. 2005, 19, 199-210. [CrossRef]

7. Chen, W.B.; Liu, W.C.; Huang, L.T. The influences of weir construction on salt water intrusion and water quality in a tidal estuary-assessment with modeling study. Environ. Monit. Assess. 2013, 185, 8169-8184. [CrossRef] [PubMed]

8. Suh, S.W.; Kim, J.H.; Yoo, S.H. Simulation of circulation and Water qualities on a partly opened estuarine lake through sluice gate. J. Korean Soc. Coast Ocean Eng. 2002, 14, 136-150.

9. Chong, S.A.; Yi, H.S.; Hwang, H.S.; Kim, H.J. Modeling the flushing effect of multi-purpose weir operation on algae removal in Yeongsan River. J. Korean Soc. Environ. Eng. 2015, 37, 563-572. [CrossRef]

10. Park, D.Y.; Park, H.S.; Kim, S.J.; Chung, S.W. Analysis of water quality variation by lowering of water level in Gangjeong-Goryeong Weir in Nakdong River. J. Environ. Impact Assess. 2019, 28, 245-262. [CrossRef]

11. National Institute of Environment Research (NIER). Development of 3-D, Time-Variable Hydrodynamic and Water Quality Model for the Water Quality Forecasting; National Institute of Environment Research: Incheon, Korea, 2011. (In Korean)

12. National Institute of Environment Research (NIER). An Advanced Research on the Water Quality Forecasting System and the Numerical Models (II); National Institute of Environment Research: Incheon, Korea, 2014. (In Korean)

13. Shin, C.M.; Kim, D.R.; Song, Y.S. Analysis of hydraulic characteristics of Yeongsan River and estuary using EFDC Model. J. Korean Soc. Water Environ. 2019, 35, 580-588. [CrossRef]

14. Ministry of Land, Infrastructure and Transport (MLIT). Master Plan for Four Major River Restoration; Ministry of Land, Infrastructure and Transport: Sejong, Korea, 2009. (In Korean)

15. Seo, K.A.; Na, J.E.; Ryu, H.S.; Kim, K.H. Characteristics of nitro-nutrients and phytoplankton dynamics in the Yeongsan River after weir construction. J. Korean Soc. Water Environ. 2018, 34, 424-431. [CrossRef]

16. Shin, C.M.; Min, J.H.; Park, S.Y.; Choi, J.K.; Kang, M.R.; Park, J.H.; Song, Y.S.; Kim, K.H. Operational water quality forecast for the Yeongsan River using EFDC model. J. Korean Soc. Water Environ. 2017, 33, 219-229. [CrossRef]

17. Yeongsan and Seomjin River Systems Management Committee. A Study for Improvement of the Water Quality and Aquatic Ecosystem of Youngsan River Estuary; Yeongsan and Seomjin River Systems Management Committee: Gwangju, Korea, 2018. (In Korean)

18. National Institute of Environment Research (NIER). Construction of a Water Quality Prediction system for Protecting Water Sources in the Han River Water System (II); National Institute of Environment Research: Incheon, Korea, 2015. (In Korean)

19. Reynolds, C.S.; Huszar, V.; Kruk, C.; Naselli-Flores, L.; Melo, S. Towards a functional classification of the freshwater phytoplankton. J. Plankton Res. 2002, 24, 417-428. [CrossRef]

20. Menden-Deuer, S.; Lessard, E.J. Carbon to Volume Relationships for Dinoflagellates, Diatoms, and Other Protist Plankton. Limnol. Oceanogr. 2000, 45, 569-579. [CrossRef]

21. National Institute of Environment Research (NIER). Construction of a Water Quality Prediction System for Protecting Water Sources in the Han River Water System (I); National Institute of Environment Research: Incheon, Korea, 2014. (In Korean)

22. Ayers, R.S.; Westcot, D.W. Water Quality for Agriculture; Food and Agriculture Organization: Rome, Italy, 1994. 